\title{
The Constitution and Synthesis of Thyroxine.
}

$A^{B O L T}$ a year ago we releffed to the work of Harington on the isolatipar the active principle of the thyroid gland and thedbnstitution and synthesis of its first degyadation product, desiodo-thyroxine (NArURe, July f0, 11066, vol. 118, p. 65). A recent paper by Harington and Barger now completes this important piece of work by proving the constitution of thyroxine itself and describing a method for its synthesis (C. R. Harington and $O$. Barger, Biochem. Journ., 1927, vol. 21, p. 169). The formula for the compound, as suggested by the previous work and proved in the present research, shows that it is a tetra-iodo derivativo of the $p$-hydroxyphenyl ether of tyrosine :

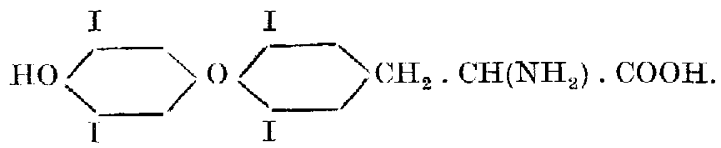

Prcvious work had proved the constitution of desiodothyroxin and its synthesis had been accomplished: the problem remaining was the position of the four iodine atoms in the molecule and their insertion by synthesis. Three considerations made it appear probable that the iodine atoms ocoupied the positions given in the above formula : first, on fusing thyroxine with potash at a high temperature in the absence of oxygen, products were obtained exhibiting pyrogallot reactions, suggesting the presence of $3: 4: 5$ trihydroxy benzene derivatives; secondly, nitrous acid and ammonia gave a colour reaction charactoristic of benzone derivatives containing two iodine atoms in the ortho position to a hydroxyl or amino group ; thirdly, on gonoral grounds it appears probable that thyroxine is synthesised in Nature from tyrosine, through the coupling of two molecules of $3: 5$ diiodotyrosine with the loss of one side-chain.

Direct iodination of dosiodothyroxine resulted in the uptake of two iodine atoms only, so that the introduction of the other two had to be effected before the phenylether synthesis was carried out. Several attempts were made to effect the synthesis, from compounds containing two iodine atoms or other easily replaceable groups in the required positions, of the body $\mathrm{CH}_{3} \mathrm{O} \cdot \mathrm{C}_{6} \mathrm{H}_{2} \mathrm{I}_{2} . \mathrm{O} \cdot \mathrm{C}_{6} \mathrm{H}_{2} \mathrm{I}_{2}$. COOT obtained by the methylation and subsequent oxidation of thyroxine, but without success.

Finally, however, a method was worked out, and the synthetic formation of this methylated oxidation product of thyroxine definitely proved the constitution of the lattcr. Quinol monomethyl ether was condensed with $3: 4: 5$ triiodonitrobenzene, to give $3: 5$ diiodo $-4-\left(4^{\prime}\right.$ methoxyphenoxy) nitrobenzene:
$\mathrm{CH}_{8} \mathrm{O} \cdot \mathrm{C}_{6} \mathrm{H}_{4} \cdot \mathrm{O} \cdot \mathrm{C}_{6} \mathrm{H}_{2} \mathrm{I}_{2} \cdot \mathrm{NO}_{2}$ (the $\mathrm{NO}_{2}$ group having a powerful mobilising effect on the halogen atom in the para position). This compound was then reduced to the aniline and the latter converted, by Sandmeyer's reaction, into the nitrile. The nitrilo, boiled with hydriodic and acetic acids underwent simultareous domethylation and hydrolysis, yielding the compound: $\mathrm{HO} . \mathrm{C}_{6} \mathrm{H}_{4} \cdot \mathrm{O} \cdot \mathrm{C}_{6} \mathrm{H}_{2} \mathrm{I}_{2} . \mathrm{COOH}$; on addition of iodine in potassium iodide to a solution of the acid in concentrated ammonia, iodine was rapidly taken up, the uptake ceasing abruptly at two mole. cules. On methylation an acid, identical in every respect with that obtained by the methylation and oxidation of thyroxine, was produced. Theso oxperiments thus settled the orientation of the iodine atoms in thyroxine, since the last two, introduced in alkaline solution, must have entered the orlho positions to the free phenolic gromp.

For the actual synthesis of thyroxine the starting point was $3: 5$ diiodo-4-(4' methoxyphenoxy) benzaldehyde; but it could not be condensed directly with a-aminopropionic acid, since the necessary re. duction would displace the iodine atoms. Some success was attainod by condensing it with hydantoin, but far botter results were seen when hippuric acid was used. Tho resulting compound

$$
\mathrm{CH}_{3} \mathrm{O} \cdot \mathrm{C}_{6} \mathrm{H}_{4} \cdot \mathrm{O} \cdot \mathrm{C}_{6} \mathrm{H}_{2} \mathrm{I}_{2} \cdot \mathrm{CH}:\left(\mathrm{C}_{3} \mathrm{O}_{2} \mathrm{~N}\right): \mathrm{C}_{6} \mathrm{H}_{5}
$$

was then converted into the a-bonzoylamino cinnamic ester:

$\mathrm{CH}_{3} \mathrm{O} \cdot \mathrm{C}_{6} \mathrm{H}_{4} \cdot \mathrm{O} \cdot \mathrm{C}_{6} \mathrm{H}_{2} \mathrm{I}_{2} \cdot \mathrm{CH}: \mathrm{C}\left(\mathrm{NH} . \mathrm{CO}, \mathrm{C}_{6} \mathrm{H}_{5}\right) \mathrm{COOLt}$,

which, on boiling with hydriodic acid and red phos. phorus, underwent dernethylation and conversion of the side-chain into $a$-aminopropionic acid. The final stage of iodination in ammoniacal solution led to the uptake of two iodine atoms and the production of a compound identical in its chemical and physiological properties with natural thyroxine.

These two syntheses, then, establish finally the constitution of thyroxine. That the synthetic product has the same physiological properties as that isolated from the thyroid gland is shown in an appendix by D. M. Lyon : the basal metabolic rate of two cases of myxœedema was raised from about -40 per cent. to normal in the course of a week by three or four intravenous injections of $4-5 \mathrm{mgm}$. of the synthetic product on alternate days. These effects are quantita. tively similar to those reported for natural thyroxine.

There can be no doubt, then, as to the identity of the artificial and natural thyroxines, and we can congratulate the authors on bringing their resoarch to a successful conclusion.

\section{The Cofkle Industry in Great Britain.}

( UR knowledge of the edible billfish of British coasts has been extendepl by Mr. F. S. Wright in his "Report on thd Cockle Beds and the Cockle Industry of England and Wales" (Fishery Investigations, Series 2, Vol. 9, No. 5, 1926. London: H.M. Stationery Office. 3s. net). Not only are his own investigations on the habits, bionomics, and growth of cockles of great value, but he has also done a great service by bringing together a mass of information on the subject which has hitherto been very scattered.

The economic value of the cockle is considerable, and its potontial value even greater. Under the best conditions, when living in wet stable sand, cockles occur in vast numbers in comparatively small areas. Mr. Wright estimated that in one bed in the Llan- rhidian Sands in South Wales, having an area of some 320 acres, there were present about four hundred and sixty-two million cockles of all sizes, the average number in each square metre being 357. A very interesting point brought out in the paper is that in some localities there are definite beds of young cockles which contain a dense population. As the cockles grow, many are forced to the surface, and these are then distributed over the general surface of the beds by the action of waves and currents. Though the enemies of the cocklo include starfish, boring gastropods, gulls, and certain fish, the greatest danger to the beds comes from frost, storms, and currents, which may destroy great numbers of cockles in the winter months. The cockle gatherers themselves do

No. 3013, Vor, 120] 
great damage with their rakes, and by leaving the young cockles which are too small for the market at the mercy of currents instead of scattering them over the beds where they can re-establish themselves. By so doing they endanger their own livelihood as well as contravene the by-laws which regulate the cockle fisheries.

The chief centres of the cockle fishery in England and Wales are the Wash, the Thames Estuary, Carmarthen Bay, and Morecambe Bay. The cockles are gathered by raking, scraping, and digging, and are usually boiled, and the soft parts separated from the shells by sieving, before they are sent away to the market. The shells have a certain value, for they are often ground up to serve as grit for poultry.

Although it has not the high carbohydrate content of the native oyster, the food value of the cockle is considerable, and, in common with similar shellfish, it provides a valuable source of food the use of which might with great profit to the community be greatly extended. It is encouraging in this connexion to note that the annual quantity of cockles landed in Great Britain increased from 167,089 cwt. in 1923 to $300,721 \mathrm{cwt}$. in 1925 , while probably many more were collected by casual gatherers. It is disconcerting, however, to learn that owing to the fact that English gatherers often refuse to take the trouble to pick out the larger cockles, which naturally command the best market, considerable quantities of cockles have been imported from Holland, where, apparently, the shellfish merchants pay more attention to the market.

C. M. Y.

D)

\section{River Pollution and Eisfieries.}

R. H. C. REDH Y has Written a useful summary of the resulfs of recent investigations upon the subject of river pollution for the International Council for the Exploration of the Sea (Rapports et ProcèsVerbaux des Réunions, vol. 43, May. Copenhagen : Andr. Fred. Høst et Fils, 1927). The direct influence upon fishes of sewage and of trade wastes containing organic matter or inorganic poisons, is discussed, and the methods used in treating the various pollutions on the Continent, in America, and in Great Britain are outlined. The report contains a comprehensive bibliography.

The disposal of noxious effluents is urgent in England, perhaps more so than on the Continent, where as a rule the towns have rivers carrying a greater quantity of water into which to discharge. As pointed out by Dr. Redeke, the capacity of the rivers for self-purification allows the discharge of effluents up to a certain concentration without material damage to the fisheries.

Waste products containing organic matter, such as domestic sewage, the wastes from sugar beet, milk, or paper factories, abattoirs, etc., require treatment before reaching the rivers by allowing a natural fauna and flora of micro-organisms to act upon them for a sufficient length of time, usually under aerobic conditions, and the removal of solid matter, whereby their putrescibility is reduced. The problems of domestic sewage disposal have been solved on these lines in a very satisfactory manner on the whole; less attention has been paid to the analogous problems presented by trade wastes where, although similar methods are reported to give satisfactory effluents, the expense of installations or area of land required has militated against their general adoption.

Trade wastes containing inorganic poisons (gasworks, coke oven, artificial silk factory effluents) or inorganic poisons and organic matter (leather, paper, textile and glue trade effluents), each require particular treatment. Small volumes of highly polluting wastes can generally be got rid of by allowing them to seep through a sufficient amount of soil before entering any watercourse, but with large quantities the expense of treatment is the major problem.

In discussing to what extent pollutions will be injurious to fisheries, Dr. Redeke lays stress upon the extent to which an effluent will be diluted on entering a river, and concludes that the degree of purity of an effluent which should be aimed at depends upon such local circumstances; the discharge of substances directly poisonous to lower animals and plants should be prohibited, for these destroy the capacity of the stream for self-purification from organic wastes.

\section{University and Educational Intelligence.}

Aв of the Iniversity of Wales, it was announced that an anorymous donor has given a sum of $£ 10,000$ for the encouragement of research.

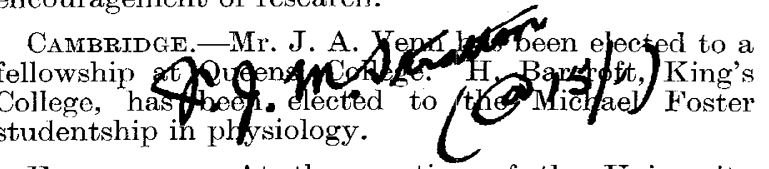

EdinbURGH.-At the meeting of the University Court on July 18, a letter was received from Prof. $J$. Cossar Ewart intimating his resignation from the chair of natural history. The frourt 4 coppted the intimation with very of regret of a expressed appreciation of the epllhent SOrices/which Prof Cossar Ewart has r ridered to the University during his long and distinguished te wure of the chair, to which he was appointed in 1882 .

On his retirement as physician to the Royal Infirmary Prof. G. Lovell Gulland intimated his resignation from the chair of medicine. The Court accepted the intimation with much regret, and resolved to record its grateful sense of the value to the University of Prof. Gulland's work as a teacher and physician.

The Court approved the terms of an ordinance founding the Buchanan chair of animal genetics, and directed that it be transmitted to the Privy Council and to the other Scottish universities. The foundation of this chair is part of the scheme for setting up a new and enlarged University Department of Research in Animal Breeding. The endowment consists of $£ 20,000$, half of which was contributed by Lord Woolavington, and half by the International Education Board of New York.

At a meeting of the Curators of Patronage of the University on July 21, Prof. J. H. Ashworth, professor of zoology in the University, was unanimously appointed professor of natural history, as from Oct. 1, in succession to Prof. J. Cossar Ewart.

London:- Dr. D. L. Mackinnon has been appointed as from yng. 1 to the University chair of zoology tenable tat King's College. Since 1919 Miss Mackinnon has been senior lecturer in zoology at King's College, and in 1921 the title of reader in zoology was conferred. lipon her. In addition to numerous papers in scientific journals, she has translated into English von Uexküll's "Theoretische Biologie" (Kegan Paul's International Library of Psychology, Philosophy, and Scientific Method, 1926), and has edited the translation from the Russian of Berg's "Nomogenesis" (Constable, 1926).

Prof. E. H. Kettle has been appointed as from October to the University chair of pathology tenable at St. Bartholomew's Hospital Medical College. Since

No. 3013, VoL. 120] 